THEMATIC SPACE: SOCIAL WORK: GENDER, RACE/ETHNICITY, GENERATIONS AND SEXUALITY

\title{
Outsourcing and the sociosexual and racial division of labor
}

\section{Rachel Gouveia Passos ${ }^{1}$}

https://orcid.org/0000-0003-2267-0200

\author{
Cláudia Mazzei Nogueira² \\ https://orcid.org/0000-0003-0130-7189
}

${ }^{1}$ Universidade Federal do Rio de Janeiro, Escola de Serviço Social, Departamento de Métodos e Técnicas, Rio de Janeiro, RJ, Brazil

${ }^{2}$ Universidade Federal de São Paulo, Instituto de Saúde e Sociedade, Programa de Pós-Graduação em Serviço Social e Políticas Sociais, Santos, SP, Brazil

\section{Outsourcing and the sociosexual and racial division of labor}

Abstract: This work seeks to analyze outsourcing with an emphasis on the socio-sexual and racial division of labor. We understand that there is differentiation about the outsourcing biases in the case of black women since Brazilian social formation is based on racism, patriarchy, and colonialism. Therefore, the article is presented in three parts: first, we bring elements that define what outsourcing is; then we approach this phenomenon in the public sector, and finally, we deal with the topic of outsourcing and its effects from the sociosexual and racial division of labor.

Keywords: Outsourcing. Precariousness. Women. Black Women. Labor.

Submitted on February 07, 2018. Approved on May 25, 2018. Reviewed on June 09, 2018.

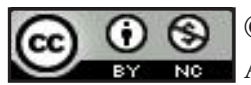

(C) The Author(s). 2018 Open Access This article is distributed under the terms of the Creative Commons Attribution-NonCommercial 4.0 International License (http://creativecommons.org/licenses/by-nc/4.0/), which permits use, distribution, and reproduction in any medium, since it's for non-commercial purposes, and provided you give appropriate credit to the original author(s) and the source, provide a link to the Creative Commons license, and indicate if changes were made. 


\section{Introduction}

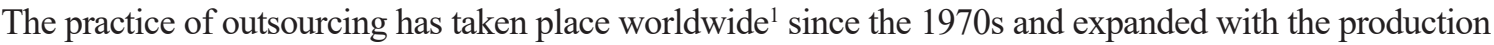
restructuring and the transformations in the world of work. It is a common type of work contract in Brazil, reaching its peak during the post-parliamentary coup that affected the deterioration of labor rights and social legislation, especially after the approval of Law 13429/2017, which establishes the rules both for outsourcing and temporary contracts, that are different from each other because of the contracting requirements and by specific articles.

Perhaps the main change brought by this law regarding outsourcing (although this is not very clear in the legislation) is that companies were now allowed to hire an outsourced workforce for both intermediate and core activities.

In an interview with Agência Brasil, the president of the Regional Labor Court of the $2^{\text {nd }}$ Region, São Paulo (TRT-2), Wilson Fernandes, stated that the outsourcing of the firm's core activity of a company would intensify the precariousness of work:

[...] if the company outsources a job, it relinquishes ten workers and hires [outsources] another ten to do their work. Why? Because it is cheaper. If it is going to be cheaper, where does the cost decrease come from? From the worker's salary, of course. (Frabasile, 2017).

It is clear that there is a new reality in outsourced work relations. This article reflects on it and is divided into three parts: first, we bring elements that define outsourcing; then we approach this phenomenon in the public sector, and finally, we deal with the topic of outsourcing and its effects from the sociosexual and racial division of labor.

\section{What is outsourcing?}

Outsourcing is yet another of the destructive ways of increasing working class precariousness. This form of flexibilization of labor not only lowers wages but also causes loss of rights. Many of the authors who research the subject affirm that this form of hiring workforce originated during World War II.

For Cruz (2009, p. 320):

[...] after the Second World War (1939-1945), the need for increased productivity in the war industry arose to maintain the supply of weapons to the countries. As large factories were unable to meet the demand, "the solution found [...] was to reshape the production process, transferring and delegating non-essential activities to other companies." (Felício, 2004, p. 81). The industry realized that it was necessary to focus on the core activity, the production of war material, delegating secondary activities to third parties.

In the same period was the emergence of the so-called welfare state, based on Keynes's principles - the State as the regulator and intervener in the economy - which expands to a great measure the Taylorist/Fordist binomial.

This economic model, however, was saturated in 1970, triggering a structural crisis of capital. Alain Bihr (1998) says that this happens because of four factors. They are: the reduction of productivity gains; the increase in the organic composition of capital (dead labor and living labor); the saturation of the social norm of consumption (Fordism implied that the process of private consumption focused on a number of durable goods such as cars, appliances); and the development of the service sector, such as commerce, management, banks, etc.

According to Antunes (1999), the response to the crisis triggered the creation of another process of reorganization of capital and its ideological and political system of domination. The most obvious example of this response is the advent of neoliberalism, which has characteristics such as the state privatization, deregulation of labor rights, and "[...] the dismantling of the state-owned productive sector, of which the Thatcher/Reagan era was the strongest expression." (Antunes, 1999, p. 31).

As a consequence, we have witnessed a clear process of dismantling workers' rights. There has been a gradual increase in work flexibility, increasing informal jobs (cash in hand) and outsourcing, resulting in the loss of labor rights. For Antunes and Druck (2015), the scenario is marked by a trend towards structural precariousness of work, in particular in Europe and the USA, where transactional capital demands this deterioration of workers' rights in the most diverse countries. Therefore, "[...] there is an expansion of the forms of precariousness and destruction of social rights that have been won with struggle by the working class since the beginning of the Industrial Revolution in England, and in Brazil especially post-1930.” (Antunes \& Druck, 2015, p. 24). 
According to Lima Neto (2008), the dissemination of outsourcing in Brazil is connected to the scenario that was implemented by President Fernando Collor's government in the early 1990s, with the central aspects being the opening of the market, the reduction of import taxes, privatization, and deregulation of the economy. For companies not to close down or declare bankruptcy, it became necessary to implement a practice of intensifying the exploitation of the working class: "[...] changing how they managed and organized work, significantly reduced costs and increased productivity, using as their primary strategy the decentralization of their activities, in some cases through outsourcing of labor." (Lima Neto, 2008, p.18).

In this period, considering that the neoliberalist ideas permeated society with significant influence, the form of capitalist production went through changes bringing about what we call production restructuring (toyotism). This restructuring, in addition to the flexibilization of labor, has increased the efficiency and the techniques of the production process, such as allowing only about $25 \%$ of goods production to be carried out within it, i.e., it horizontalizes the production process and transfers much of what was previously produced within it to third parties (Antunes, 1999).

According to Marcelino (2004, p. 127), this outsourcing, which has expanded significantly, "[...] has a great scope [...]: while it reduces labor costs, it also promotes the division between the workers."

Another author who discusses the subject is Krein (2007, p. 197). He states that some forms of hiring also

[...] can be considered as outsourcing, such as subcontracting through an employment agency [a B2B contract], the legal entity, the "autonomous proletariat", home-office work and the cooperative for business. Outsourcing is not limited to these forms of contracting since it encompasses the entire process of externalizing activities for other companies or individuals, which has intensified since the 1990 s with economic changes and the process of production restructuring.

The author adds:

By acquiring a new look with modern management techniques ${ }^{2}$, outsourcing manifests itself quite differently in several economic segments: from subcontracting a network of suppliers with independent production, through hiring specialized companies to provide support services and through the allocation of temporary work through the employment agency, until the hiring of a legal entity or a self-employed person in the productive and essential areas of the company, home-office work (which is most often informal), organization of work cooperatives, production or sectors for former employees etc. The complexity of the phenomenon has increased to the point that it is possible to observe the outsourcing of the outsourced work. Also, in some cases, there is the process called [in Portuguese] quarteirizaçã $o^{3}$.

It is possible to affirm that the practice of outsourcing has a central objective of reducing costs, through the flexibilization of work, transferring to others the risks and the labor responsibilities, which results in the intensification of the precariousness ${ }^{4}$ of the workforce both male and female.

In an interview given to Correio da Cidadania, professor and researcher Ricardo Antunes, expressed his preoccupation about the political decisions that occurred in Brazil in 2017, saying that 2017 was "the year that perhaps should not have existed." (Brito, 2017). For the researcher, we live a process of naturalization of misery and a system of classes that overexploits the poorest and most miserable. Meanwhile, the conservative middle class is only concerned with maintaining its consumerism power.

To Carta Capital, Antunes picks up elements dealt with in his book Adeus ao Trabalho? [Goodbye to Work?]. In the work that completed 22 years of publications in 2017, Antunes pointed to what he calls "an era of precarious work on a global scale." (Nunes, 2017). Practices that would be considered as exceptions in the past became the rule during President Michel Temer's government, i.e., the precarious and outsourced work in Brazil is now a widespread practice. Also, Ricardo Antunes makes a metaphorical allusion to slave labor. For him, in slavery, the worker was sold and now, in the era of outsourcing, they are rented. Researcher and professor Virgínia Fontes (2017), discusses this phenomenon from the notion of expropriation of workers' rights based on the uberization of work. In full agreement with Antunes and Fontes, we were able to identify in our research that this process of outsourcing, the precariousness of the workers of the public sector, presents elements and objectives that have similarity to that of the private sector. 


\section{Outsourcing in the public sector}

In addition to private companies, some sectors of public institutions also use a form of outsourced contracting with the same objective of reducing costs and transferring responsibility in the execution of legal labor obligations. It should be noted that public services have undergone a process of restructuring, following the mercantile logic. Thus, the public sector went through changes, adopting operational performance similar to that of private companies. In Brazil, this could be observed during the counter-reform of the State that occurred in President Fernando Henrique Cardoso's government.

Even though there has been the dissemination of outsourcing practices in the last decades, this form of contracting in the Brazilian public sector, has been occurring for many years. According to Souza (2012, pp. 56-57),

\footnotetext{
Regarding regulation, outsourcing in the public administration is not a recent practice, considering that the legislation is provided by the Decree-law n. 200/67. This legal device refers to the process of decentralization of the public service, and establishes that the core activities of public administration are "public planning, coordination, supervision, and control" and may indirectly carry out complementary activities, by contracting specialized companies (Carelli, 2007, p. 60). Thus, the process of decentralization is guided by three fundamental points:

a) within the personnel of the Federal Administration, clearly distinguishing the levels of management and operation;

b) from the Federal Administration to that of the state government, when they are appropriately equipped and by legal agreement [in Brazil, convênio];

c) from the Federal Administration to the private organizations, through contracts or concessions. (Decreto-lei n. 200, 1967).
}

The outsourcing in the public sector in Brazil was accentuated during the State Reform - which occurred during the mandate of President Cardoso - when, according to a survey by the Departamento Intersindical de Estatística e Estudos Socioeconômicos (DIEESE) (2003, p. 23):

[...] for the government to overcome the national economic crisis, it would be necessary to have a gradual reconstruction or a reform of the State, which would mean, among other things, the limitation of the State's role in the economy. This limitation would be achieved by transferring some activities to the private sector or to the so-called non-state public sector, which includes non-profit organizations, or Third Sector.

According to DIEESE (2003, p. 23), during the 1990s and early 2000s "[...] the reform that was carried out adopted, what is called in public administration, a managerial paradigm. It replaced a bureaucratic culture of processes control, seeking to implement market-like mechanisms in public management". In other words, this market-like logic consisted of guiding the public administration "[...] to control results, to seek effectiveness and efficiency, as well as to adopt a more flexible management in the area of Human Resources" (DIEESE, 2003, p. 23). Thus, for DIEESE (2003, p. 23), "the State should delegate some of its activities to third parties or other partners as a way of containing the growth of the public deficit and the size of the administrative apparatus."

Thus, the State should act only in the activities considered as exclusive, "[...] emphasizing at the top, a strategic command center, and, horizontally, the secretaries formulating public policies, the executive, and the regulatory agencies." (DIEESE, 2003, p. 24).

According to this new formulation of State activities, the ones related to the social and scientific sphere, including "[...] schools, universities, scientific and technological research centers, day care centers, outpatient clinics, hospitals, welfare institutions, museums, symphony orchestras and others" (DIEESE, 2003, p. 24), should no longer be the state's exclusive responsibility. When trying to explain the practices of outsourcing of the public sector, DIEESE (2003, p. 24) adds

$[\ldots]$ there would be no reason for these activities to remain within the State, but their privatization would not be justified either, since they would by nature be activities heavily subsidized by the State, in addition to voluntary donations from society. The so-called "publicization" was defended for these activities, which means that these activities would be transferred to the non-state public sector or third sector. The publicization program implemented at that time created the "Organizações Sociais" [Social Organizations] (OSs), institutions legally established as public entities under private law, which can enter into management contracts with the state and thus be financed partially or even entirely by the public budget. Finally, the 
production of goods and services for the market should be left under the aegis of its own laws, and the State is withdrawn from these sectors of the economy through privatization programs.

Also, DIEESE (2003, p. 25) says,

After building the new structure of the State, it was time to establish the "main activities" where the State exercises its power (making laws and regulations, judging, policing, monitoring, policymaking and offering leadership). The strategic center, the medium public administration of the State and the "complementary activities or services" (cleaning, surveillance, transport, technical services of computer science and data processing, among others) were activities to be emphasized.

Accordingly, "[...] complementary services should, a priori, be outsourced, that is, submitted to public bidding and contracted with third parties." (DIEESE, 2003, p. 25). However, some support services very close to the exclusive activities of the State were not recommended for outsourcing.

For these specific services, the option was a change in the employment relationship. The single legal system, created by the 1988 Constitution, was altered, and two legal systems of hiring within the Brazilian State emerged: statutory employees and public employees governed by the Consolidação das Leis Trabalhistas - CLT [Consolidation of Labor Laws]. (DIEESE, 2003, p. 25).

Thus, these elements indicate that outsourcing in the public sector has followed the same path as the private sector, that is, precariousness of the workforce. Therefore, we understand that outsourcing, whether in the private or public sector, is a structuring element of the precariousness of work and it has shown signs of expansion in both sectors. Another important factor identified in the research is that, in a way, outsourcing has sex and race. There are more outsourcing of women than men, especially black women.

\section{Outsourcing and sociosexual and racial division of labor}

As previously shown, outsourcing is a clear way of intensifying workforce precariousness in both the public and private sectors, while maintaining the specificities of the job position. We know that in the private sector the main purposes of outsourcing are: 1 . Reduction of labor costs; 2 . Increased productivity; 3 . The existence of a clearer political component of fragmenting the working class between outsourcers and workers regularly contracted under the CLT, which in turn further divides the worker's union. Outsourcing in the public sector is not primarily aimed at increasing profits since profit is not a goal of a public company, but because, in the neoliberal context, public companies are increasingly following a market oriented logic, outsourcing ends up becoming the introduction of private practices within the public company. This means that over time, public companies have private activities, carried out by outsourced private organizations, which ends up introjecting a commercial and privative practice that is undermining the public enterprise. Therefore, outsourcing and, consequently, the expansion of work precariousness, may be reaching black and poor women even more.

It is thought that outsourced jobs, both in public and in the private sector, are focused on service delivery, which has characteristics such as low remuneration, repetitive jobs, low qualification requirements, as it is in the case of cleaning and janitorial jobs, which are usually filled by women.

For example, Souza (2012, pp. 59-60), when analyzing the public sector, state that:

The effects of outsourcing on public administration are also perverse on the conditions of work and remuneration, such as low wages, in some cases no benefits, poor safety conditions, more significant exposure to the risks of psychopathology and work pathology. Also, the situation is exacerbated by noncompliance with labor obligations, such as vacation pay, access to FGTS [a severance pay fund], INSS [social security] and indemnities at the end of the contracts. (Augusto Júnior et al. 2012, p. 122-123). Such conditions are indicators of work precariousness, which is aggravated when analyzed from a gender perspective, including issues such as moral and sexual harassment.

Although Souza (2012) works on the situation in the public administration, it is important to observe that the reality in the private sector when it comes to outsourcing is not very different, because all these concerns regarding non-compliance with labor rights (vacation pay, INSS, FGTS and other indemnities when a contract is terminated) are present in both sectors. 
According to DIEESE's technical note about Law 13429/2017, that provides for new forms of outsourcing, the legislation is "[...] excessively general and omits various aspects of labor relations in service companies and between them and contractors." (DIEESE, 2017, p. 10). The technical note also explains that the "Law expressively excludes from the new regulation the companies in the business of surveillance and transportation of securities, but it is not clear whether the new rules on outsourcing are valid to the public sector or the domestic work." (DIEESE, 2017, p. 10). These regulatory voids bring legal uncertainty to private companies and public institutions, as well as to workers, and may lead to increased judicialization, if not clarified and resolved (Article 19-B). Also, these "[...] omissions may lead to an increase in labor and legal insecurity for workers and companies, thus motivating an increase in labor lawsuits." (DIEESE, 2017, p. 10).

The debate on outsourcing practices had been on the agenda since 2004, and the discussion was accelerated by President Temer's government. The effects of passing the Law are catastrophic and perverse, leading to the deepening of racial, gender and class inequalities already existing in Brazil. According to DIEESE (2017, p. 11), the approval of Law 13429/2017, “[...] together with other measures proposed in bill 6787/2016 $6^{5}$, that alters the CLT, and bill 287 to amend the Constitution, which is related to the pension reform, will drastically affect, for the worse, the living conditions of Brazilian workers."

When cutting across gender and race to analyze the labor market and the effects of the social and racial division of labor, great inequality was observed regarding the relationship between men and women and white women and black women. It should be noted that these inequalities result from racism and patriarchy since both are ideologies of domination in the process of formation of Brazilian society (Moura, 1994; Saffioti, 1976). In this sense, we emphasize that social relations in Brazil were formed and consolidated based on class exploitation and inequality, and on the oppression of gender and race/ethnicity expressed in the data presented in this study.

In 2014, the Instituto Brasileiro de Geografia e Estatística (IBGE) published a synthesis of the research carried out in the years 2012-2013, identifying that the majority of workers with a formal contract are white women (58.4\%). Black (which includes here the Brazilian pardo population) women make up the most significant proportion of domestic workers $(57.0 \%)$.

The Instituto de Pesquisa Econômica Aplicada (IPEA)

[...] we want to make the point that the subalternity of black women's work in Brazilian society is connected to our social formation. Therefore, it is worth mentioning that black women are the ones that accumulate the worst social indicators in Brazil [...] (2017) has published the report Retrato das Desigualdades de Gênero e Raça [Portrait of Gender and Race Inequalities], which presents a survey using data from IBGE between 1995 and 2015. According to the report, "[...] between 1995 and 2015, the female participation rate ranged from 54-55\%, never reaching 60\%. This means that almost half of Brazilians of working age are out of the job market." (IPEA, 2017, p. 2). Regarding the market insertion, in 2015, the unemployment rate for women was $11.6 \%$ and for men, $7.8 \%$. About black women, the proportion reached 13.3\%. "The highest unemployment rates are observed among black women with complete or incomplete high school (9 to 11 years of schooling): in this group, the unemployment rate in 2015 was $17.4 \%$." (IPEA, 2017, p. 2).

The IPEA's report opens space to discuss the effects of women's double shift of work. When the research analyzes gender and race inequalities about the household arrangements, it is observed that $64 \%$ of black women are living below the poverty line (Júnia, 2017). Regarding access to income, "[...] a significant reduction in the proportion over the period analyzed can be observed: among black women, $46.7 \%$ did not have income in 1995, compared to $27.3 \%$ in 2015." (IPEA, 2017, p. 2).

In her doctorate research, Passos (2016), studied the reality of the caregivers of residential therapeutic services in the municipality of Rio de Janeiro, in 2014, and found that of the 258 outsourced workers identified, $72 \%$ were black and 26\% white. The study carried out in 2014-2015 by Lima and Carvalho (2016) with outsourced cooks working in the basic and higher education institution Colégio Pedro II, in the campus of Realengo (Rio de Janeiro), identified that the majority of the workers were black and resident of neighborhoods in the periphery. Regarding cleaning services, where outsourcing is widespread, the researcher Patrícia Galvão points out that the majority of the workers are black (Severo, 2017). Diana Assunção (2013) shows in her book A precarização tem rosto de mulher [Precarization Has a Woman's Face] that most of the outsourcers who work as cleaners at the University of São Paulo are women and residents of the favelas around the university. 
A country that has in its social structure traces of the slave system, where land and revenues are concentrated in the hands of few as nowhere else in the world; governed by regional and retrograde oligarchs; a country in which the concentration of income entirely or partially excludes $80 \%$ of its population from the possibility of enjoying a decent standard of living; which has 30 million children abandoned, deprived or criminalized, cannot be a racial democracy. (Moura, 1994, p. 63).

Finally, we want to make the point that the subalternity of black women's work in Brazilian society is connected to our social formation. Therefore, it is worth mentioning that black women are the ones that accumulate the worst social indicators in Brazil, according to reports from Rede Brasil Atual ("Mulheres Negras," 2017), because they perceive the lowest wages, suffer the domestic violence, the most obstetric violence and they are the ones that die the most. Therefore, these indices represent the bases of Brazilian sociability, rooted in racism ${ }^{6}$, patriarchy ${ }^{7}$, and colonialism ${ }^{8}$. Therefore, it is critical to uncover the inequalities and oppressions that structure our society in order to seek its overcoming and transformation.

In a survey conducted by the Federal University of Rio de Janeiro and reported by the newspaper "O Dia" [The Day] in 2014, the researcher and economist Marcelo Paixão pointed out that in Brazil, of every five black women in the labor market, one is doing domestic cleaning work (20\%). The researcher considers this is a revealing percentage, because "it is more or less the percentage observed in the Census of 1872, before the Lei Aurea [Law that abolished slavery in Brazil], which resulted in $25 \%$ of the women slaves doing domestic cleaning work." (Paixão, 2014 as cited in Passos, 2017, p. 89).

Outsourcing is just one of the expressions of the deepening of Brazilian inequalities in the contemporary scenario. However, we cannot forget that, as shown by Assunção (2013, p. 50), the process of labor precarization and outsourcing "[...] has its first and main target in the socially subordinated groups in society, such as women, black people, homosexuals (men and women) and immigrants." Therefore, in order to move towards the transformation of society, the struggle for the end of oppression/exploitation of gender, race and class cannot be separated from overcoming private property.

\section{Final considerations}

The discussion above brings evidence that outsourcing is indeed a way of intensifying the precariousness of the workforce and, specifically the female workforce. The objective of outsourcing practices is to reduce public expenditures when considering the different levels of government (municipal, state and federal), as well as to reduce the expenses of companies, considering the private sphere. It also has the characteristic of transferring the responsibilities for the workers' social rights to third parties and, thus, diminish the contractor responsibility towards the personnel.

More specifically in the case of working black women, they are in an extremely fragile and unstable situation and are often hampered when outsourced firms go through bankruptcies. In addition to not having job stability of any kind, they are not guaranteed access to the labor rights provided in the CLT in the case of termination of outsourced services. Moreover, with the new legislation, the situation becomes much worse, as the rights have been further relaxed.

It should also be noted that black and poor women are at the base of the Brazilian social pyramid, and they are the ones who perform the most precarious, subordinate, invisible jobs with the worst pay, as usually found in outsourced jobs. There is a differentiation about the outsourcing bias in the case of women, especially black women since the Brazilian social formation is based on the inequality and oppression of class, gender and race/ethnicity.

Another critical factor is the absence of a connection between these workers and the workers' unions, since there is a difficulty in recognizing to which working category they belong, so they are not able to recognize the union that best represents their interests. Finally, these reflections do not intend to exhaust the topic discussed here. They are an attempt to leverage the debate about the inequalities of class, gender and race/ethnicity reproduced in Brazilian society, and that permeate the world of work.

\section{References}

Antunes, R. (1999). Os sentidos do trabalho. São Paulo: Boitempo.

Antunes, R., \& Druck, G. (2015). A terceirização sem limites: a precarização do trabalho como regra. O Social em Questão, 18(34), 1940 . 
Assunção, D. (2013). A precarização tem rosto de mulher (2nd ed). São Paulo: Iskra.

Augusto Júnior, F. et al. (2009). Terceirização no setor público brasileiro. In D. M. Dau, I. J. Rodrigues, \& J. J. Conceição (Orgs.), Terceirização no Brasil: do discurso da inovação à precarização do trabalho (atualização do debate e perspectivas). São Paulo: Annablume: CUT.

Bihr, A. (1998). Da grande noite à alternativa. São Paulo: Boitempo.

Braga, R. (2015). A pulsão plebeia: trabalho, precariedade e rebeliões sociais. São Paulo: Alameda.

Decreto-lei n. 200, de 25 de fevereiro de 1967. Dispõe sobre a organização da Administração Federal, estabelece diretrizes a Reforma Administrativa e dá outras providências. Retrieved from http://www.planalto.gov.br/ccivil_03/Decreto-Lei/Del0200.htm

Lei n. 13.429, de 31 de março de 2017. Altera dispositivos da Lei no 6.019, de 3 de janeiro de 1974 que dispõe sobre o trabalho temporário nas empresas urbanas e dispõe sobre as relações de trabalho na empresa de prestação de serviços e terceiros. Retrieved from http://www.planalto.gov.br/ccivil_03/_Ato2015-2018/2017/Lei/L13429.htm

Brito, G. (2017, December 23). 2017, o ano que não deveria ter existido [Interview]. Correio da Cidadania. Retrieved from http:// www.correiocidadania.com.br/34-artigos/manchete/13007-2017-o-ano-que-nao-deveria-ter-existido

Carelli, R. (2007). Terceirização e direitos trabalhistas no Brasil. In G. Duck, \& T. Franco (Orgs.), A perda da razão social do trabalho (pp. 59-68). São Paulo: Boitempo.

Colli, J. (2000). A trama da terceirização: um estudo do trabalho no ramo da tecelagem. Campinas: Unicamp.

Coutinho, G. F. (2011). Terceirização bancária no Brasil: Direitos Humanos violados pelo Banco Central. São Paulo: LTr.

Cruz, L. G. R. (2009). A terceirização trabalhista no Brasil: aspectos gerais de uma flexibilização sem limite. Revista do CAAP, (1), 319343 .

Departamento Intersindical de Estatística e Estudos Socioeconômicos. (2003). O processo de terceirização e seus efeitos sobre os trabalhadores no Brasil (Relatório técnico). Brasília: Author.

Departamento Intersindical de Estatística e Estudos Socioeconômicos. (2017). Impactos da Lei 13.429/2017 (antigo PL 4.302/1998) para os trabalhadores: Contrato de trabalho temporário e terceirização (Nota técnica, n. 175). Brasília: Author.

Frabasile, D. (2017, March 27). Lei da terceirização: muda para pior ou para melhor a vida do trabalhador? Época Negócios. Retrieved from http://epocanegocios.globo.com/Economia/noticia/2017/03/entenda-o-efeito-da-lei-da-terceirizacao-para-o-trabalhador.html

Faria, M. G. D. (1999). Terceirização: (des)fordizando a fábrica, um estudo de complexo petroquímica da Bahia. São Paulo: Boitempo. Felício, A. M., \& Henrique, V. L. (2004). Terceirização: caracterização, origem e evolução jurídica. In G. N. Delgado, \& C. A. J. Henrique (Coords.), Terceirização no Direito do Trabalho (pp. 81-118). Belo Horizonte: Mandamentos.

Fontes, V. (2017). Capitalismo em tempos de uberização: do emprego ao trabalho. Marx e o Marxismo, 5(8), pp. 45-67.

Instituto Brasileiro de Geografia e Estatística. (2014). Síntese de Indicadores Sociais: uma análise das condições de vida da população brasileira. Rio de Janeiro: Author.

Instituto de Pesquisa Econômica Aplicada. (2017). Retrato das desigualdades de gênero e raça: 1995 a 2015. Brasília: Author.

Júnia, R. (2017, December 15). IBGE: Desigualdade é grande no país; 25\% da população vivem com R\$ 387 por mês. Radioagência Nacional. Retrieved from http://radioagencianacional.ebc.com.br/economia/audio/2017-12/ibge-desigualdade-e-grande-no-pais-25-dapopulacao-vivem-com-r-387-por-mes/

Krein, J. D. (2007). Tendências recentes nas relações de emprego no Brasil: 1990-2005 (Tese de Doutorado em Economia Social e do Trabalho). Universidade Estadual de Campinas, Campinas, SP, Brasil.

Lima, R. M., \& Carvalho, E. C. (2016). Destinos traçados? Gênero, raça e precarização e resistência entre merendeiras do Rio de Janeiro. Revista da ABET, 15(1), 114-126.

Lima Neto, W. M. R. (2008). Quando a terceirização não funciona: a "primeirização" das atividades de manutenção industrial na Caraíba Metais (Dissertação de Mestrado Profissional em Administração). Escola de Administração, Universidade Federal da Bahia, Salvador, BA, Brasil.

Matos, J. N., \& Domingos, N. (2012). Novos proletários: a precariedade entre a “classe média” em Portugal. Lisboa: Le Monde Diplomatique.

Marcelino, P. R. P. (2004). A logística da precarização: terceirização do trabalho na Honda. São Paulo: Expressão Popular.

Moura, C. (1983). Escravismo, colonialismo, imperialismo e racismo. Revista Afro-Ásia, (14), 124-137.

Moura, C. (1994). Particularidades do racismo brasileiro. Revista Princípios, (32), 62-64.

Nogueira, C. M. F. M. (2004). A feminização no mundo do trabalho. Campinas, SP: Autores Associados.

Nogueira, C. M. F. M. (2011). O trabalho duplicado (2nd ed). São Paulo: Expressão Popular.

Nunes, D. (2017, May 17). “Na escravidão o trabalhador era vendido. Na terceirização, é alugado" [Interview]. Carta Capital. Retrieved from https://www.cartacapital.com.br/sociedade/201 cna-escravidao-o-trabalhador-era-vendido-na-terceirizacao-ele-e-alugado201d

Passos, R. G. (2016). Trabalhadoras do Care na saúde mental: contribuições marxianas para a profissionalização do cuidado feminino (Tese de Doutorado em Serviço Social). Programa de Estudos Pós-Graduados em Serviço Social, Pontifícia Universidade Católica de São Paulo, São Paulo, SP, Brasil.

Passos, R. G. (2017). "De escravas a cuidadoras": invisibilidade e subalternidade das mulheres negras na política de saúde mental brasileira. O Social em Questão, 20(38), 77-94.

Mulheres negras acumulam piores indicadores sociais no Brasil. (2017, November 17). Rede Brasil Atual. Retrieved from http:// 
www.redebrasilatual.com.br/cidadania/2017/11/mulheres-negras-acumulam-piores-indicadores-sociais-no-brasil Saffioti, H. (1976). A mulher na sociedade de classes: mito e realidade. Petrópolis: Vozes.

Sanches, A. T. (2006). Terceirização e terceirizados no setor bancário: relações de emprego, condições de trabalho e ação sindical (Dissertação de Mestrado em Ciências Sociais). Programa de Estudos Pós-Graduados em Ciências Sociais, Pontifícia Universidade Católica de São Paulo, São Paulo, SP, Brasil.

Severo, V. S. (2017, April 26). Terceirização: a precarização da proteção à mulher e à criança. Justificando. Retrieved from http:// justificando.com/2017/04/26/terceirizacao-a-precarizacao-da-protecao-a-mulher-e-a-crianca/

Souza, E. S. (2012). A “maquiagem" do trabalho formal: um estudo do trabalho das mulheres terceirizadas no setor de limpeza na Universidade Federal da Bahia (Dissertação de Mestrado em Ciências Sociais). Programa de Pós-Graduação em Ciências Sociais, Universidade Federal da Bahia, Salvador, BA, Brasil.

\section{Notes}

1 The theme is discussed in depth in the works of Matos and Domingos (2012) and Braga (2015).

2 "Outsourcing is not a new practice in the capitalist production. It is gradually becoming more frequent in recent years in the context of the production restructuring and organizational adjusts by companies, reducing costs at the same time as gaining in productivity and competitiveness. ([Faria], 1999; Colli, 2000).”(Krein, 2007, p. 188).

3 "The quarteirização as defined by Sanches, "[...] refers both to the company that intermediate, that is positioned between the "parent-company" and the contracted company, i.e., one manages the contracts with the service providers; and deals with a deployment of ouotsourcing, represented by the movement in which the service providers contracted by the "parent-company" hand over the job to another firm, "cooperative of workers" (“autonomous" workers) or liberal professionals." (Sanches, 2006, p. 24).”(Krein, 2007, p. 188).

4 This reality is pointed out in the research by the following authors: Colli (2000), in the textile industry; Faria (1999), in the chemical industry; Coutinho (2011), in banks; Souza (2012), in the cleaning sector at the Federal University of Bahia; and Nogueira (2011), in telemarketing.

5 Bill 6787 of 2016 alters the Consolidation of Labor Laws (CLT), which was passed by the Decree-Law 5452 of May 1, 1943; and the Laws 6019 of January 3, 1974; 8036 of May 11, 1990; and 8212 of July 24, 1991; in order to adjust the legislation to the new labor relations.

6 See Moura $(1983,1994)$.

7 See Saffioti (1976) and Passos (2016).

8 See Moura $(1983,1994)$.

\section{Rachel Gouveia Passos}

rachel.gouveia@gmail.com

Doctor of Social Work from Graduate Program in Social Work of the Pontifícia Universidade Católica de São Paulo (PUC-SP)

Assistant Professor at the Department of Methods and Techniques of the School of Social Work of the Universidade Federal do Rio de Janeiro (UFRJ)

\section{UFRJ}

Av. Pasteur, 250 - Urca

Rio de Janeiro - Rio de Janeiro - Brazil

CEP: $22.290-240$

\section{Cláudia Mazzei Nogueira}

mazzeinogueira@uol.com.br

Doctor of Social Work from Graduate Program in Social Work of the Pontifícia Universidade Católica de São Paulo (PUC-SP)

Associate Professor at the Undergraduate Course in Social Work and at the Graduate Program in Social Work and Social Policies of the Universidade Federal de São Paulo (UNIFESP)

\section{UNIFESP}

Rua Silva Jardim, 136 - Vila Matias

Santos - São Paulo - Brazil

CEP: $11.015-020$ 
Acknowledgments

We thank UNIFESP for the infrastructure provided and the CNPq for the scholarship granted.

\section{Funding}

Junior Post-Doctoral Fellowship of the National Council of Scientific and Technological Development (PDJ/CNPq) - Process: 150076/2017-7.

Duration: from March 2017 to February 2018.

\section{Authors' contributions}

Both authors worked to organize and write this article. It is the result of the advising sessions carried out during the Post-Doctoral of Rachel Gouveia Passos, advised by Cláudia Mazzei Nogueira.

\section{Ethics approval and consent to participate}

Approved by the Ethics Committee of UNIFESP - Process: 7622260117.

\section{Consent for publication}

Not applicable.

\section{Competing interests}

There are no competing interests for the proceedings of this publication. 